\title{
Diallel analysis using graphical \& numerical approach for grain yield \& its attributes in bread wheat (Triticum aestivum L.)
}

Gita R. Chaudhari ( $\sim$ geetchaudhary89@gmail.com )

Anand Agricultural University

\section{A. Patel}

Anand Agricultural University

A. D. Kalola

Anand Agricultural University

Sushil Kumar

Anand Agricultural University

\section{Research Article}

Keywords: Half diallel, t2 value, Wr-Vr graph, Regression value (b), Additive gene and Non-additive gene, genetic variance

Posted Date: March 2nd, 2022

DOI: https://doi.org/10.21203/rs.3.rs-1401490/v1

License: (9) This work is licensed under a Creative Commons Attribution 4.0 International License.

Read Full License 
Diallel analysis using graphical \& numerical approach for grain yield \& its attributes in bread wheat (Triticum aestivum $\mathrm{L}$.)

Gita R. Chaudhari ${ }^{\text {* }}$, D. A. Patel ${ }^{1}$, A. D. Kalola ${ }^{2}$ and Sushil Kumar ${ }^{3}$

${ }^{1}$ Department of Genetic \& Plant Breeding, BACA, Anand Agricultural University, Anand, Gujarat, India

${ }^{2}$ Department of Statistics, BACA, Anand Agricultural University, Anand, Gujarat, India

${ }^{3}$ Department of Agricultural Biotechnology, Anand Agricultural University, Anand, Gujarat, India

*email: geetchaudhary89@gmail.com

\begin{abstract}
Ten wheat (Triticum aestivum L.) genotypes are crossed in half diallel fashion. Components of gene effect revealed that most of the characters were governed by both additive and dominance gene effect across the environments with greater influence of dominance gene effect except for days to $50 \%$ heading, days to maturity and grain yield per main spike. The estimated ' $\mathrm{t}$ ', values were found significant for all the character except days to $50 \%$ heading, which indicates the failure of assumptions of diallel analysis. The over dominance behaviour was observed for days to $50 \%$ heading, days to maturity, no. of effective tillers per plant , length of main spike, no. of spikelets per main spike, no. of grains per main spike, grain yield per main spike and 1000 grain weight. The array points on the $\mathrm{Wr}-\mathrm{Vr}$ graph expected to fall on the line of unity (450) and the value of regression "b" was unity for days to $50 \%$ heading and 1000 grain weight which revealed an absence of digenic interactions for these characters and rest of the characters had non-random distribution of genes at different loci among the parents and/ or presence of inter allelic interaction at different loci.
\end{abstract}

Key words

Half diallel, $\mathrm{t}^{2}$ value, Wr-Vr graph, Regression value (b), Additive gene and Non-additive gene, genetic variance

\title{
INTRODUCTION
}

Wheat (Triticum aestivum L.) is the world's most important cereal being the chief source of staple food for about one third of global population ${ }^{1}$. To cope with the problem of everincreasing population in the country, it appears to be a dire need to enhance the productivity of this cereal grain. So, in bread wheat, breeding based on economic traits had been receiving maximum attention for a long time and this factor, has been fully exploited ${ }^{2}$. Hence an estimate of gene action is important in launching a successful breeding programme. During 
breeding of high yielding varieties of crop plants, breeders are continually challenged with the problem of parent selection. Though elimination of poor crosses on the basis of their performance in initial generation has been suggested; but information on the genetic architecture of yield and its components will help to sort out the improved crosses more competently ${ }^{3}$. Several reports in the past indicate that the diallel analysis is the easiest method of understanding the genetic nature of quantitatively inherited traits and to ascertain the prepotency of parents. Diallel analysis helps in understanding the genetic control of the trait, which guides the breeder to advance and select segregating populations. There are several approaches available for analysis of diallel crosses but the two main approaches being followed are Griffing's and Hayman's approaches. These two approaches are often used together for complementary data interpretation ${ }^{4}$.

The nature of gene action involved in the inheritance of various characters is very important to decide any breeding methodology for crop improvement. This can be determined by graphical approach ( $\mathrm{Vr}-\mathrm{Wr}$ graph). The $\mathrm{Vr}-\mathrm{Wr}$ statistic provides an estimate of the relative number of dominance to recessive genes present in the common arrays of the parents, with the $\mathrm{Vr}$ and $\mathrm{Wr}$ statistics, calculated from diallel tables, graphs can be drawn and the geometric representation of these statistics can be interpreted. The position of the regression line in the graph indicates the degree of dominance and we can construct parabola limits in this graph. The interpretation of the results of this analysis is easy and straight forward if the main assumptions of the diallel analysis are fulfilled ${ }^{4}$. Kearsey ${ }^{5}$ noted that Hayman and Jink's diallel analysis $^{6}$ deliver more evidence than other methods, but has more necessary assumptions. Diallel analysis by Griffing ${ }^{7}$ do not afford any test to detect epistasis or linkage but Hayman and Jink's analysis do provide such test. When using Griffing's analysis to estimate variance components, it has been suggested that simple tests, such as the $\mathrm{Wr}-\mathrm{Vr}$ evaluation found in Hayman ${ }^{\mathbf{8}}$ model, may be used to ascertain the presence of epistasis and/or

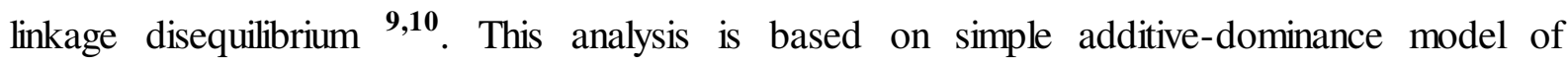
gene effects with certain assumptions. The validity of the hypothesis of additive-dominance model was tested by confirming unit slope of regressions of $\mathrm{Wr}$ and $\mathrm{Vr}$ and by nonsignificant value of $\mathrm{t}^{2}$ as prescribed by Hayman ${ }^{\mathbf{8}}$.

In the present Study the diallel analysis given by Jinks and Hayman ${ }^{6}$ and Hayman ${ }^{11}$ was employed to find out the genetic constitution of the parents with respect to various traits and to assess the gene action in all the ways for different quantitative characters in bread wheat that could be utilized in specific breeding programme for achieving fruitful results. 


\begin{tabular}{|c|c|c|c|}
\hline $\begin{array}{l}\text { Sr. } \\
\text { No. }\end{array}$ & Genotypes & Pedigree & Source \\
\hline 1 & GW 451 & $\begin{array}{llll}\text { GW324/4/CROC_1/AE.SQUARROSA } & \text { (205) /JUP/ } \\
\text { JY/3/ SKAUZ /4/ KAUZ /5/ GW } 339 & & \\
\end{array}$ & \multirow{13}{*}{$\begin{array}{c}\text { Regional Research Station, } \\
\text { Anand Agricultural } \\
\text { University, Anand-388110 }\end{array}$} \\
\hline 2 & GW 496 & HD 2285 / CPAN 1861 & \\
\hline 3 & LOK 1 & S 308 / S 311 & \\
\hline 4 & GW 322 & PBW 173 / GW 196 & \\
\hline 5 & GW 366 & DL 802-3 / GW 232 & \\
\hline 6 & HI 1544 & HIND162/BOBW HITE/CPAN 2099 & \\
\hline 7 & GW 173 & TW 275 -7-6-10 / LOK1 & \\
\hline 8 & GW 11 & LOK 1 / HW 1042 // LOK 1 & \\
\hline 9 & HD 2864 & DL509-2/DL377-8 & \\
\hline 10 & UAS 385 & GW344/UAS239/DWR162 & \\
\hline \multicolumn{3}{|c|}{ Standard check varieties } & \\
\hline 1 & MASC $6222-$ TS & HD 2189*2//MASC 2496 & \\
\hline 2 & HD $2932-$ LS & KAUZ/STAR//HD 2643 & \\
\hline
\end{tabular}

Table 1: List of genotypes and their pedigree information

\begin{tabular}{|c|c|c|}
\hline Environments & Sowing time & Season \& Year \\
\hline $\mathrm{E}_{1}$ & Normal & \multirow{2}{*}{ Rabi 2018-19 } \\
\hline $\mathrm{E}_{2}$ & Late & \multirow{2}{*}{ Rabi 2019-20 } \\
\hline $\mathrm{E}_{3}$ & Normal & \\
\hline $\mathrm{E}_{4}$ & Late & \\
\hline
\end{tabular}

Table 2: Environments under study 


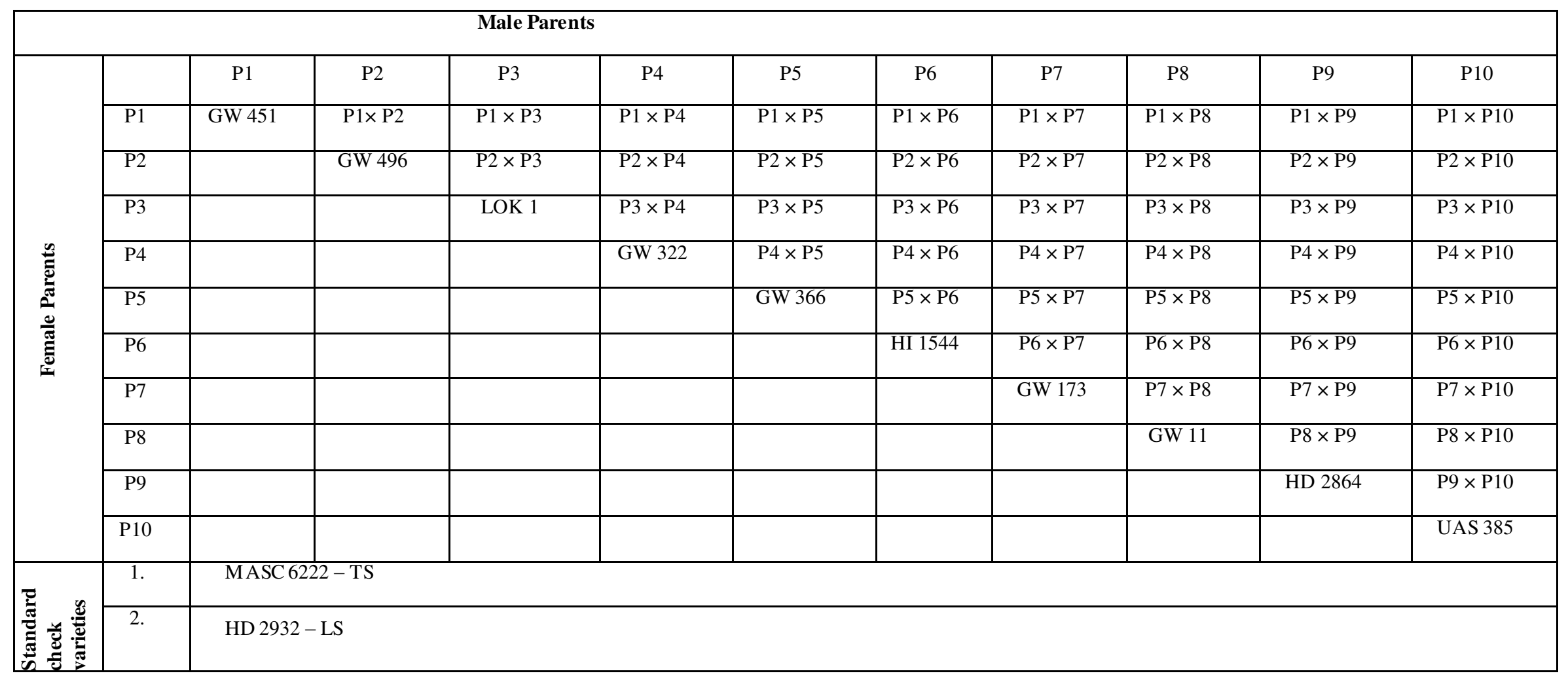

Table 3: Crossing pattern in $10 \times 10$ half diallel crosses in wheat 


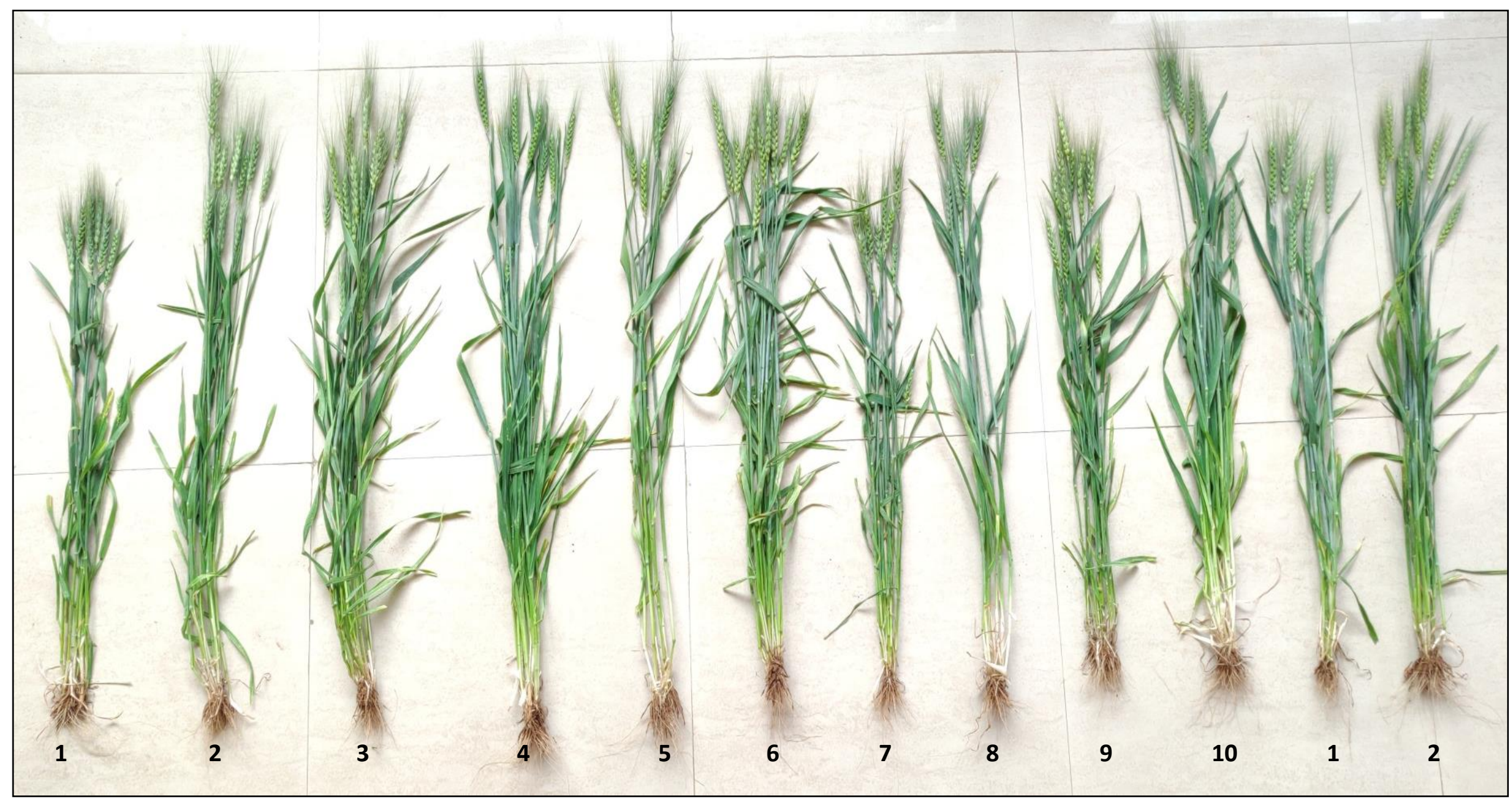

Fig 1: Plant stature of parents and checks 


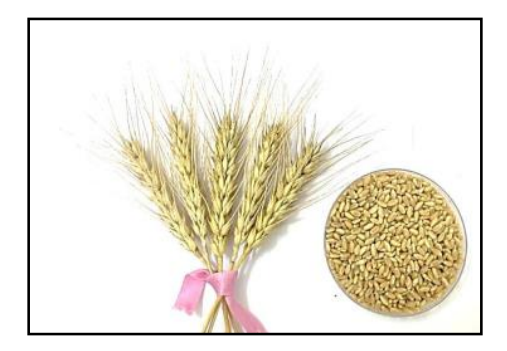

GW 451

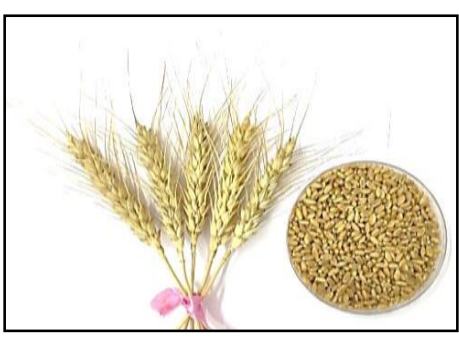

HI 1544

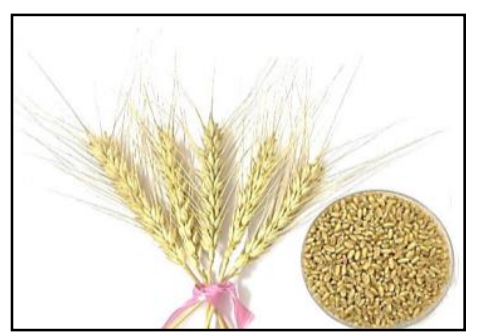

GW 496

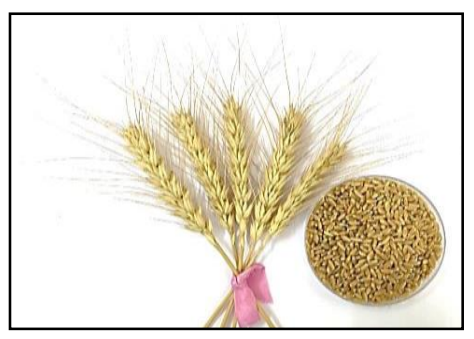

GW 173

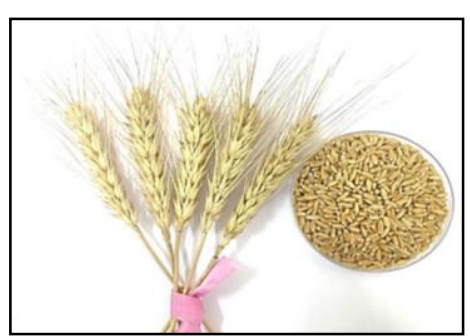

LOK 1

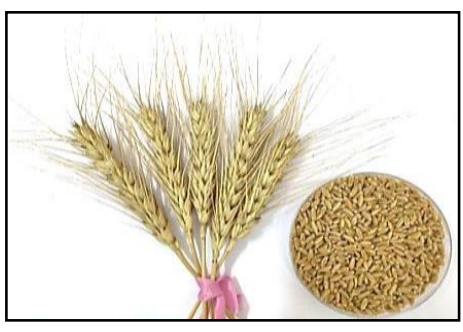

GW 11

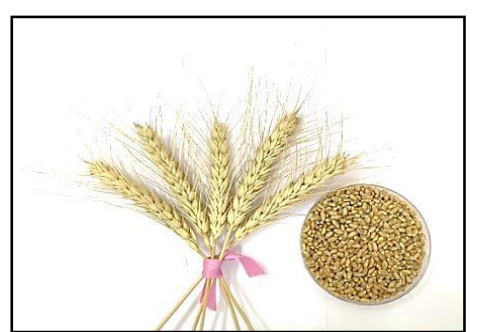

GW 322

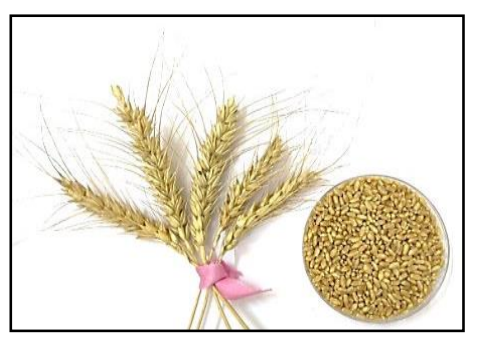

HD 2864

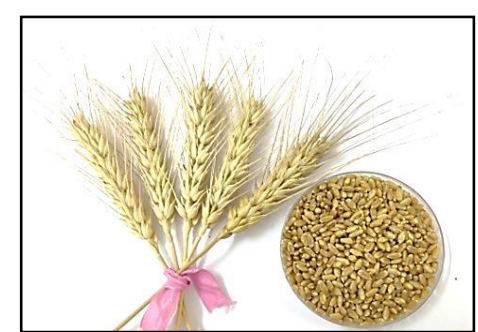

GW 366

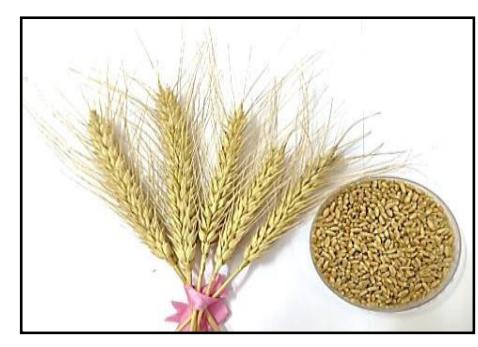

UAS 385

Fig 2: Spike and grain charactistics of parents 


\section{Graphical and Numerical approach}

The numerical analysis was carried out as per procedures outlined by Hayman ${ }^{\mathbf{8 , 1 1 - 1 4}}$ and Jinks ${ }^{15,16}$ as described in details by Mather and Jinks ${ }^{17}$ and Singh and Chaudhary ${ }^{18}$ and Graphical approach as per Jinks and Hayman ${ }^{6}$ and Hayman ${ }^{8}$. This analysis is based upon following assumptions: 1. Diploid segregation 2. No differences in reciprocal crosses i.e. no maternal effect. 3. Independent action of non-allelic genes in the diallel cross i.e. absence of epistatsis 4. Homozygous parents 5. Genes independently distributed between the parents i.e. no linkages 6. No multiple allelism. To test failure of any of the assumptions of diallel analysis, ' $\mathrm{t}^{2}$ ' test was applied as suggested by Hayman ${ }^{11}$; however, ' $\mathrm{t}^{2}$ ' also test the adequacy of basic assumption of additive dominance model. A non-significant value of ' $\mathrm{t}$ ' ' would indicate the uniformity of the $\mathrm{W}_{\mathrm{r}}-\mathrm{V}_{\mathrm{r}}$, and confirms validity of hypothesis postulated, particularly adequacy of additive dominance model.

\section{Estimation of genetic parameters}

After observing adequacy of additive dominance model, the components of genetic variation viz., $\mathrm{D}, \mathrm{H}_{1}, \mathrm{H}_{2}, \mathrm{E}, \mathrm{F}$ and $\mathrm{h}^{2}$ were estimated. The component analysis was only performed for the data which fitted the additive dominance model. These genetic components of variation were calculated from the diallel table following the methods given by Hayman ${ }^{\mathbf{1 1}}$.

\section{COMPONENTS OF GENETIC VARIANCE}

\section{Numerical Approach}

The estimated ' $\mathrm{t}^{2}$ ' values for different characters in each individual environment are presented in Table 4. Out of twelve characters studied, the estimated ' $\mathrm{t}$ ', values were found significant for two characters viz., plant height, grain yield per plant and biological yield per plant over all the environments; however, the estimates were non-significant over all the environments for one character i.e., days to $50 \%$ heading. Moreover, for rest of the characters, ' $\mathrm{t}^{2}$, value was significant either in $\mathrm{E}_{1}, \mathrm{E}_{2}, \mathrm{E}_{3}$ and $\mathrm{E}_{4}$ in combination of either of the environments. Significance of ' $\mathrm{t}^{2}$, suggested failure of certain assumptions of diallel analysis. Therefore, components of gene effect and related parameters have been presented and discussed for the characters, where ' $\mathrm{t}^{2}$, estimate of uniformity of the $\mathrm{Wr}-\mathrm{Vr}$ value was nonsignificant (Table 5 and 6).

\section{Days to $50 \%$ heading}


The value of " $\mathrm{t}^{2}$ ", was non-significant in all environments. Significance of additive (D) and dominance components $\left(\mathrm{H}_{1}\right.$ and $\left.\mathrm{H}_{2}\right)$ of gene effect revealed that the character was governed by both additive as well as dominance gene actions in all the environments. The estimates of average degree of dominance suggested the existence of over dominance gene action in all environment $\left(\mathrm{E}_{1}: 1.69 \%, \mathrm{E}_{2}: 1.20 \%, \mathrm{E}_{3}: 1.50 \%\right.$ and $\left.\mathrm{E}_{4}: 1.23 \%\right)$. Asymmetrical distribution of positive and negative alleles among the parents was observed in all environments as values of $\mathrm{H}_{2} / 4 \mathrm{H}_{1}$ ratio was less than 0.25 . The positive values of $\mathrm{F}$ and more than one ratio of $\mathrm{KD} / \mathrm{KR}$ indicated that the character was indicated an excess of dominant genes in analysis except $\mathrm{E}_{1}$. At least one dominant gene or group of genes appeared to govern the character as $\mathrm{h}^{2} / \mathrm{H}_{2}$ ratio was less than one across the environments. The dominant gene or group of genes was not computed as $\mathrm{h}^{2}$ values were positive or non-significant. The estimates of narrow sense heritability was low to medium in all analysis $\left(\mathrm{E}_{1}: 24.58 \%, \mathrm{E}_{2}: 48.33 \%, \mathrm{E}_{3}\right.$ : $30.33 \%$ and $\left.\mathrm{E}_{4}: 49.69 \%\right)$.

\section{Days to maturity}

The value of " $\mathrm{t}^{2}$ " test was found to be significant in $\mathrm{E}_{1}$, while, for rest of environments it was non-significant. Significance of additive (D) and dominance components $\left(\mathrm{H}_{1}\right.$ and $\left.\mathrm{H}_{2}\right)$ of gene effect revealed that the character was governed by both additive as well as dominance gene effects in all environments; however preponderance gene effects was noticed through magnitude of component of gene effects

The estimates of average degree of dominance suggested the existence of over dominance gene action in all environments $\left(\mathrm{E}_{2}: 1.97 \%, \mathrm{E}_{3}: 1.55 \%\right.$ and $\left.\mathrm{E}_{4}: 1.90 \%\right)$. Asymmetrical distribution of positive and negative alleles among the parents was observed in all environments as value of $\mathrm{H}_{2} / 4 \mathrm{H}_{1}$ ratio was less than 0.25 . The positive values of $\mathrm{F}$ and more than one ratio of $\mathrm{KD} / \mathrm{KR}$ was observed in all the analysis which indicated the excess of dominant genes among parents. At least one dominant gene or group of genes appeared to govern the character as $\mathrm{h}^{2} / \mathrm{H}_{2}$ ratio was less than one across the environments. The dominant gene or group of genes was not computed as $\mathrm{h}^{2}$ values were positive or non-significant. The estimates of narrow sense heritability were low in all the environments $\left(E_{1}: 19.21 \%, E_{2}\right.$ : $28.64 \%$ and $\mathrm{E}_{3}: 18.35 \%$ ), which also confirmed that character was under control of dominance gene effects. 


\begin{tabular}{|c|c|c|c|c|c|c|c|c|c|}
\hline \multirow{2}{*}{ SN } & \multirow{2}{*}{ Characters } & \multicolumn{4}{|c|}{$\mathrm{t}^{2}$ test } & \multicolumn{4}{|c|}{ b (Regression) } \\
\hline & & $\mathbf{E}_{1}$ & $\mathbf{E}_{2}$ & $\mathbf{E}_{\mathbf{3}}$ & $\mathbf{E}_{4}$ & $\mathbf{E}_{1}$ & $\mathbf{E}_{2}$ & $\mathbf{E}_{\mathbf{3}}$ & $\mathbf{E}_{4}$ \\
\hline 1 & Days to $50 \%$ heading & 1.96 & 0.20 & 0.60 & 0.04 & $0.18++$ & $0.87 \$ \$$ & $0.15+$ & $0.69 \$$ \\
\hline 3 & Plant height & $6.21 * *$ & $9.56^{* *}$ & $10.18^{* *}$ & $19.17 * *$ & $0.19++$ & $0.20++$ & $0.06++$ & $0.17++$ \\
\hline 4 & No. effective tillers per plant & 1.34 & $13.53 * *$ & 0.45 & $18.10 * *$ & $0.20++$ & $-0.13++$ & $0.36+$ & $-0.11++$ \\
\hline 5 & Length of main spike & $3.96 * *$ & 1.31 & 0.93 & $21.47 * *$ & $0.13++$ & $0.16++$ & $0.37+$ & $0.22 \$++$ \\
\hline 7 & Number of grains per main spike & 3.01 & 0.208 & $6.68 * *$ & 0.24 & $-0.07++$ & 0.57 & $0.04++$ & 0.65 \\
\hline 8 & Grain yield per main spike & $34.90 * *$ & 0.004 & $21.91 * *$ & 0.04 & $0.10++$ & $0.14+$ & $0.08++$ & 0.20 \\
\hline 9 & Grain yield per plant & $29.21 * *$ & $7.32 * *$ & $43.61 * *$ & $7.99 * *$ & $0.22 \$++$ & $0.01++$ & $0.21 \$++$ & $0.13++$ \\
\hline 10 & 1000 grain weight & 1.81 & 0.04 & 0.97 & 0.006 & $0.67 \$ \$+$ & $0.46 \$ \$++$ & $0.71 \$ \$$ & $0.66 \$$ \\
\hline 11 & Biological yield per plant & $476.05^{* *}$ & $7.14 * *$ & $88.27 * *$ & $8.41 * *$ & $-0.04++$ & $0.04++$ & $-0.06++$ & $0.20++$ \\
\hline
\end{tabular}

$*, * *$ Significant at $5 \%$ and $1 \%$ levels, respectively , \$,\$ Significant at $5 \%$ and $1 \%$ levels, respectively when Ho: $b=0 ;+,++$ Significant at $5 \%$ and $1 \%$ levels, respectively when Ho: $\mathrm{b}=1$

Table 4: " $\mathrm{t}^{2}$ " value and regression coefficient for different metric characters of Wr on $\mathrm{Vr}$ 


\begin{tabular}{|c|c|c|c|c|c|c|c|c|c|c|c|}
\hline \multicolumn{5}{|c|}{ Days to $50 \%$ heading } & \multicolumn{3}{|c|}{ Days to maturity } & \multicolumn{2}{|c|}{$\begin{array}{c}\text { No. of effective tillers } \\
\text { per plant }\end{array}$} & \multicolumn{2}{|c|}{ Length of main spike } \\
\hline$\widehat{\mathrm{D}}$ & $17.32 * *$ & $7.37 * *$ & $19.04 * *$ & $7.09 * *$ & $5.11 * *$ & $10.15^{* *}$ & $2.93 * *$ & 0.87 & 0.74 & 0.13 & 0.13 \\
\hline$\widehat{\mathrm{F}}$ & -2.16 & $5.22 * *$ & 1.58 & $5.73 * *$ & 2.04 & 1.19 & $0.82 * *$ & -0.08 & -1.04 & -0.19 & 0.13 \\
\hline$\widehat{\mathrm{H}}_{2}$ & $41.79 * *$ & $9.36^{* *}$ & $36.90^{* *}$ & $8.75 * *$ & $13.80^{* *}$ & $17.58^{* *}$ & $8.21 * *$ & $8.25 * *$ & $7.89 * *$ & $1.45^{* *}$ & $1.55^{* *}$ \\
\hline$\widehat{\mathrm{h}}^{2}$ & 10.64 & 0.01 & 11.33 & 0.23 & 3.41 & 4.76 & 4.25 & 0.08 & 0.04 & $0.88 * *$ & $1.22 * *$ \\
\hline$\left(\widehat{\mathrm{H}}_{1} / \widehat{\mathrm{D}}\right)^{0.5}$ & 1.69 & 1.20 & 1.50 & 1.23 & 1.97 & 1.55 & 1.90 & 3.59 & 3.59 & 3.79 & 4.01 \\
\hline$\widehat{\mathrm{H}}_{2} / 4 \widehat{\mathrm{H}}_{1}$ & 0.21 & 0.22 & 0.22 & 0.20 & 0.17 & 0.18 & 0.19 & 0.18 & 0.21 & 0.20 & 0.18 \\
\hline
\end{tabular}

$\mathrm{KD} / \mathrm{KR}=\left\{\left(4 \widehat{\mathrm{D}}_{1}\right)^{0.5}+\widehat{\mathrm{F}}\right\} /\left\{\left(4 \widehat{\mathrm{D}}_{1}\right)^{0.5}-\widehat{\mathrm{F}}\right\} ; * * *$ Significant at 5 and 1 per cent levels, respectively

Table 5: Genetic components for days to $\mathbf{5 0 \%}$ heading, days to maturity, No. of effective tillers per plant and Length of main spike 


\begin{tabular}{|c|c|c|c|c|c|c|c|c|c|c|c|c|c|}
\hline \multicolumn{4}{|c|}{ No. of spikelets per main spike } & \multicolumn{3}{|c|}{ No. of grains per main spike } & \multicolumn{2}{|c|}{$\begin{array}{c}\text { Grain yield per } \\
\text { main spike }\end{array}$} & \multicolumn{4}{|c|}{1000 grain weight } & \multirow{2}{*}{$\begin{array}{c}\begin{array}{c}\text { Harvest } \\
\text { index }\end{array} \\
E_{1}\end{array}$} \\
\hline $\begin{array}{c}\text { Genetic } \\
\text { components }\end{array}$ & $\mathbf{E}_{2}$ & $\mathbf{E}_{\mathbf{3}}$ & $\mathbf{E}_{4}$ & $\mathbf{E}_{1}$ & $\mathbf{E}_{2}$ & $\mathbf{E}_{\mathbf{4}}$ & $\mathbf{E}_{2}$ & $\mathbf{E}_{4}$ & $\mathbf{E}_{1}$ & $\mathbf{E}_{2}$ & $\mathbf{E}_{\mathbf{3}}$ & $\mathbf{E}_{4}$ & \\
\hline$\widehat{\mathrm{E}}$ & $0.49 * *$ & $0.39 * *$ & $0.36^{* *}$ & 1.53 & $6.85 * *$ & 3.14 & 0.02 & 0.01 & 0.63 & 0.64 & 1.01 & 0.79 & 9.34 \\
\hline$\widehat{\mathrm{D}}$ & $2.01 * *$ & 0.82 & $2.19 * *$ & 17.21 & $23.12 * *$ & $21.02 * *$ & $0.09 * *$ & $0.10 * *$ & $12.46^{* *}$ & $30.12 * *$ & $13.82 * *$ & $30.78 * *$ & 66.93 \\
\hline$\widehat{\mathrm{F}}$ & -0.31 & -0.28 & 0.53 & 12.26 & 2.40 & 4.56 & 0.19 & $0.23 * *$ & -4.71 & 12.56 & -0.54 & 14.22 & 115.29 \\
\hline$\widehat{\mathrm{H}}_{1}$ & $5.26 * *$ & $5.04 * *$ & $4.47 * *$ & $98.85^{* *}$ & $109.88 * *$ & $121.19 * *$ & $0.49 * *$ & $0.45^{* *}$ & $41.62 * *$ & $68.97 * *$ & $37.71 * *$ & $62.35 * *$ & $357.26^{* *}$ \\
\hline$\widehat{\mathrm{H}}_{2}$ & $4.81 * *$ & $3.87 * *$ & $3.86 * *$ & $79.04 * *$ & $78.17 * *$ & $85.93 * *$ & $0.35 * *$ & $0.29 * *$ & $32.99 * *$ & $52.25^{* *}$ & $30.82 * *$ & $47.28 * *$ & $290.10^{* *}$ \\
\hline$\widehat{\mathrm{h}}^{2}$ & $11.25^{* *}$ & -0.13 & $5.63 * *$ & 13.29 & $33.53^{* *}$ & $35.67 * *$ & $0.15^{* *}$ & 0.07 & $77.41 * *$ & $85.02 * *$ & $76.95^{* *}$ & $90.71 * *$ & 59.62 \\
\hline$\left(\widehat{\mathrm{H}}_{1} / \widehat{\mathrm{D}}\right)^{0.5}$ & 1.62 & 2.48 & 1.43 & 2.40 & 2.18 & 2.40 & 2.38 & 2.07 & 1.83 & 1.51 & 1.65 & 1.42 & 2.31 \\
\hline$\widehat{\mathrm{H}}_{2} / 4 \widehat{\mathrm{H}}_{1}$ & 0.23 & 0.19 & 0.22 & 0.20 & 0.18 & 0.18 & 0.18 & 0.16 & 0.20 & 0.19 & 0.20 & 0.19 & 0.20 \\
\hline $\mathrm{KD} / \mathrm{KR}$ & 0.91 & 0.87 & 1.19 & 1.35 & 1.05 & 1.09 & 2.65 & 3.37 & 0.81 & 1.32 & 0.98 & 1.39 & 2.19 \\
\hline$\widehat{\mathrm{h}}^{2} / \widehat{\mathrm{H}}_{2}$ & 2.34 & -0.03 & 1.46 & 0.17 & 0.43 & 0.42 & 0.43 & 0.24 & 2.35 & 1.63 & 2.50 & 1.92 & 0.21 \\
\hline $\begin{array}{l}\% \text { Heritability } \\
\text { (narrow sense) }\end{array}$ & 21.06 & 10.58 & 28.99 & 15.65 & 14.62 & 13.99 & 18.27 & 29.12 & 20.31 & 33.80 & 24.63 & 37.49 & 19.32 \\
\hline
\end{tabular}

$\mathrm{KD} / \mathrm{KR}=\left\{\left(4 \widehat{\mathrm{D}}_{1}\right)^{0.5}+\widehat{\mathrm{F}}\right\} /\left\{\left(4 \widehat{\mathrm{D}}_{1}\right)^{0.5}-\widehat{\mathrm{F}}\right\} ; * * *$ Significant at 5 and 1 per cent levels, respectively

Table 6: Genetic components for no. of spikelets per main spike, no. of grains per main spike, grain yield per main spike, 1000 grain weight and harvest index 


\section{No. of effective tillers per plant}

The value of " $\mathrm{t}^{2}$ " test was significant in $\mathrm{E}_{2}$ and $\mathrm{E}_{4}$, which suggested failure of certain assumptions of diallel analysis. Significance of only both the dominance components $\left(\mathrm{H}_{1}\right.$ and $\mathrm{H}_{2}$ ) of gene effect in $\mathrm{E}_{1}$ and $\mathrm{E}_{3}$ clearly indicated that was mainly governed by dominance gene effect. The estimate of average degree of dominance (3.59) suggested existence of over dominance. Asymmetrical distribution of positive and negative alleles among the parents was observed as value of $\mathrm{H}_{2} / 4 \mathrm{H}_{1}$ was less than expected value 0.25 . The negative value of $\mathrm{F}$ and below one ratio of $\mathrm{KD} / \mathrm{KR}$ indicated that the character was controlled by more number of recessive genes. Less than one estimate of $\mathrm{h}^{2} / \mathrm{H}_{2}$ ratio indicated that at least one dominant group of genes appear to govern this trait. The dominant gene or group of genes was not computed as $\mathrm{h}^{2}$ values were positive or non-significant. The estimate of narrow sense heritability was extremely low in $\mathrm{E}_{1}(6.53 \%)$ and $\mathrm{E}_{2}(5.91 \%)$, which also confirmed that character was under control of dominance gene effect.

\section{Length of main spike}

The value of " $\mathrm{t}$ " " test was significant in $\mathrm{E}_{1}$ and $\mathrm{E}_{4}$, which suggested failure of certain assumptions of diallel analysis. Significance of only dominance components $\left(\mathrm{H}_{1}\right.$ and $\left.\mathrm{H}_{2}\right)$ of gene effect in $\mathrm{E}_{2}$ and $\mathrm{E}_{3}$ revealed that the character was solely governed by dominance gene action. The estimates of average degree of dominance (H1/D) ${ }^{0.5}$ suggested existence of over dominance gene actions. The below 0.25 values of $\mathrm{H}_{2} / 4 \mathrm{H}_{1}$ ratio indicated asymmetrical distribution of positive and negative alleles among the parental genotypes.

The negative $F$ value and below one ratio of $K D / K R$ observed in $E_{2}$ indicated that character was controlled by more number of recessive genes; however in $\mathrm{E}_{3}$, character was mainly governed by more number of dominant genes as values of $\mathrm{F}$ was positive and ratio of $\mathrm{KD} / \mathrm{KR}$ was above unity. The estimates of $\mathrm{h}^{2} / \mathrm{H}_{2}$ ratio indicated that at least one dominant group of genes appeared of govern this trait in $\mathrm{E}_{2}$ and $\mathrm{E}_{3}$. Significant and positive estimates of $\mathrm{h}^{2}$ in both environments indicated evidence for net dominance gene effect sum over loci. The estimates of narrow sense heritability were low in both $\mathrm{E}_{2}(4.69 \%)$ and $\mathrm{E}_{3}(5.01 \%)$.

\section{No. of spikelets per main spike}

For number of spikelets per main spike, " $\mathrm{t}^{2}$ " test was found to be significant in $\mathrm{E}_{1}$, while for rest of the environments it was non-significant. However, greater influence of additive gene effect in $\mathrm{E}_{2}$ and $\mathrm{E}_{4}$ and dominance components $\left(\mathrm{H}_{1}\right.$ and $\left.\mathrm{H}_{2}\right)$ of gene effect were 
significant in $E_{2}$ and $E_{4}$ with preponderance of dominant gene effect, while only dominance gene effect governed the character in $\mathrm{E}_{3}$. The values of average degree of dominance indicated existence of over dominance in all the three environments. The below 0.25 values of $\mathrm{H}_{2} / 4 \mathrm{H}_{1}$ ratio indicated asymmetrical distribution of positive and negative alleles among the parental genotypes. The negative $\mathrm{F}$ value and below one ratio of $\mathrm{KD} / \mathrm{KR}$ that the character was mainly controlled by more number indicated preponderance of recessive genes in $\mathrm{E}_{2}$ and $\mathrm{E}_{3}$. The positive value of $\mathrm{F}$ and above one ratio of $\mathrm{KD} / \mathrm{KR}$ indicated that the character was controlled by excess of dominant genes in $\mathrm{E}_{4}$. The estimate of $\mathrm{h}^{2} / \mathrm{H}_{2}$ ratio was above two in $E_{2}$ and above one in $E_{4}$ and one dominant group of genes appeared to govern this character, respectively. The estimate of narrow sense heritability was low in $\mathrm{E}_{2}(21.06 \%), \mathrm{E}_{3}(10.58 \%)$ and $\mathrm{E}_{4}(28.99 \%)$, which also confirmed that character was largely under control of dominance gene effect.

\section{No. of grains per main spike}

The value of " $\mathrm{t}^{2}$ " test was found to be significant in $\mathrm{E}_{3}$, while for rest of the environments it was non-significant. Additive (D) and dominance components $\left(\mathrm{H}_{1}\right.$ and $\left.\mathrm{H}_{2}\right)$ of gene effect were significant in $\mathrm{E}_{2}$ and $\mathrm{E}_{4}$ with preponderance of dominant gene effect, while an only dominance gene effect was involved in $\mathrm{E}_{1}$. The values of average degree of dominance indicated existence of over dominance. The values of $\mathrm{H}_{2} / 4 \mathrm{H}_{1}$ ratio below 0.25 indicated asymmetrical distribution of positive and negative alleles among the parental lines in $E_{1}, E_{2}$ and $E_{4}$. The positive values of $F$ and more than one values of $K D / K R$ indicated symmetrical distribution of dominant and recessive genes among the parental genotypes, and dominant genes were excess across the environments.

Less than one estimate of $\mathrm{h}^{2} / \mathrm{H}_{2}$ ratio indicated that at least one dominant group of genes appear to govern this trait. Significant and positive estimates of $h^{2}$ in $E_{2}$ and $E_{4}$ indicated evidence for net dominance gene effect sum over loci. The estimates of narrow sense heritability was low in $\mathrm{E}_{1}(15.65 \%), \mathrm{E}_{2}(14.62 \%)$ and $\mathrm{E}_{3}(13.99 \%)$.

\section{Grain yield per main spike}

The value of " $\mathrm{t}$ " " test was significant in $\mathrm{E}_{1}$ and $\mathrm{E}_{3}$, which suggested failure of certain assumptions of diallel analysis. Significance of additive (D) and dominance components $\left(\mathrm{H}_{1}\right.$ and $\mathrm{H}_{2}$ ) of gene effect in $\mathrm{E}_{2}$ and $\mathrm{E}_{4}$ revealed that the character was governed by both additive and dominance gene action. The estimate of average degree of dominance $\left(\mathrm{E}_{2}: 2.38\right.$ and $\left.\mathrm{E}_{4}: 2.07\right)$ suggested existence of over dominance. Asymmetrical distribution of positive and 
negative alleles among the parents was observed as value of $\mathrm{H}_{2} / 4 \mathrm{H}_{1}$ was less than expected value 0.25 . The positive value of $F$ and above one ratio of $K D / K R$ indicated that the character was controlled by excess of dominant genes. Less than one estimate of $h^{2} / \mathrm{H}_{2}$ ratio indicated that at least one dominant group of genes appear to govern this trait. Significant and positive estimate of $\mathrm{h}^{2}$ observed in $\mathrm{E}_{2}$ indicated evidence for net dominance gene effect sum over loci. The estimate of narrow sense heritability was low in $\mathrm{E}_{2}(18.27 \%)$ and $\mathrm{E}_{4}$ (29.12\%), which also confirmed that character was under control of dominance gene effect.

\section{0 grain weight}

The value of " $\mathrm{t}^{2}$ " was non-significant in all the analysis. Significance of additive (D) and dominance components $\left(\mathrm{H}_{1}\right.$ and $\left.\mathrm{H}_{2}\right)$ of gene effect revealed that the character was governed by both additive as well as dominance gene actions in all environments. The estimates of average degree of dominance suggested existence of over dominance gene action in all environments. The below 0.25 values of $\mathrm{H}_{2} / 4 \mathrm{H}_{1}$ ratio indicated asymmetrical distribution of positive and negative alleles among the parental genotypes in all the environments. The positive value of $\mathrm{F}$ and above one ratio of $\mathrm{KD} / \mathrm{KR}$ indicated that the character was controlled by excess of dominant genes in $E_{2}$ and $E_{4}$, when negative value of $F$ and below one ratio of $\mathrm{KD} / \mathrm{KR}$ indicated that that the character was controlled by more number of recessive gene in $\mathrm{E}_{1}$ and $\mathrm{E}_{3}$. More than one estimate of $\mathrm{h}^{2} / \mathrm{H}_{2}$ ratio indicated that more than two and three dominant groups of genes appeared to govern this character. Significant and positive estimates of $\mathrm{h}^{2}$ in all the environments indicated evidence for net dominance gene effect sum over loci. The estimates of narrow sense heritability were low and medium in all the analysis $\left(\mathrm{E}_{1}: 20.31 \%, \mathrm{E}_{2}: 33.80 \%, \mathrm{E}_{3}: 24.63 \%\right.$ and $\left.\mathrm{E}_{4}: 37.49 \%\right)$.

\section{Harvest index}

The value of " $\mathrm{t}^{2}$ " test was significant in $\mathrm{E}_{2}, \mathrm{E}_{3}$ and $\mathrm{E}_{4}$, which suggested failure of certain assumptions of diallel analysis. Significance of only dominance components $\left(\mathrm{H}_{1}\right.$ and $\mathrm{H}_{2}$ ) of gene effect in $\mathrm{E}_{1}$ revealed that the character was solely governed by dominance gene action. The estimate of average degree of dominance (2.31) suggested existence of over dominance. Asymmetrical distribution of positive and negative alleles among the parents was observed as value of $\mathrm{H}_{2} / 4 \mathrm{H}_{1}$ was less than expected value 0.25 . The positive value of $\mathrm{F}$ and above one ratio of $\mathrm{KD} / \mathrm{KR}$ indicated that the character was controlled by more number of dominant genes. Less than one estimate of $\mathrm{h}^{2} / \mathrm{H}_{2}$ ratio indicated that at least one dominant group of genes appear to govern this trait. The estimate of narrow sense heritability was low 
(19.32\%), which also confirmed that character was largely under control of dominance gene effect.

\section{Discussion of Numerical approach}

Components of gene effect revealed that most of the characters were governed by both additive and dominance gene action across the environments with greater influence of dominance gene effect except for days to $50 \%$ heading in $\mathrm{E}_{1}, \mathrm{E}_{2}, \mathrm{E}_{3}$ and $\mathrm{E}_{4}$; days to maturity in $E_{2}, E_{3}$ and $E_{4}$; grain yield per main spike in $E_{4}$; while, for no. of effective tillers per plant $\left(E_{1}\right.$ and $\left.E_{3}\right)$, length of main spike $\left(E_{2}\right.$ and $\left.E_{3}\right)$, no. of spikelets per main spike $\left(E_{3}\right)$, no. of grains per main spike $\left(\mathrm{E}_{1}\right)$ and harvest index $\left(\mathrm{E}_{1}\right)$ only dominance component $\left(\mathrm{H}_{1}\right.$ and $\left.\mathrm{H}_{2}\right)$ of gene effect was significant. The findings were also claimed the involvement of both additive and non-additive gene action in the inheritance of yield and related traits in bottlegourd ${ }^{19,20}$.

The values of average degree of dominance varied across the environments. The over dominance behaviour of interacting alleles was depicted for days to $50 \%$ heading $\left(\mathrm{E}_{1}, \mathrm{E}_{2}, \mathrm{E}_{3}\right.$ and $\left.E_{4}\right)$, days to maturity $\left(E_{2}, E_{3}\right.$ and $\left.E_{4}\right)$, no. of effective tillers per plant ( $E_{1}$ and $\left.E_{3}\right)$, length of main spike ( $E_{2}$ and $\left.E_{3}\right)$, no. of spikelets per main spike $\left(E_{2}, E_{3}\right.$ and $\left.E_{4}\right)$, no. of grains per main spike $\left(E_{1}, E_{2}\right.$ and $\left.E_{4}\right)$, grain yield per main spike $\left(E_{2}\right.$ and $\left.E_{4}\right), 1000$ grain weight $\left(E_{1}, E_{2}\right.$, $E_{3}$ and $\left.E_{4}\right)$ and harvest index $\left(E_{1}\right)$. The higher proportions of dominant genes observed in most of the characters are in agreement with the findings ${ }^{21}$. Thus, the additive and dominance both the variances were pre dominance component governing the expression of yield and other yield components accordance $w^{2} \mathbf{i t h}^{22}$. The findings were also found non-additive gene action playing important roles in controlling grain yield under both drought stress and favorable growing environments ${ }^{23}$

Asymmetrical distribution of positive-negative and dominance-recessive genes was depicted for most of the characters. However, excess of dominant genes were exhibited for days to $50 \%$ heading $\left(E_{2}, E_{3}\right.$ and $\left.E_{4}\right)$, days to maturity $\left(E_{2}, E_{3}\right.$ and $\left.E_{4}\right)$, length of main spike $\left(E_{3}\right)$, no. of spikelets per main spike $\left(E_{4}\right)$, no. of grains per main spike $\left(E_{1}, E_{2}\right.$ and $\left.E_{4}\right)$, grain yield per main spike $\left(E_{2}\right.$ and $\left.E_{4}\right), 1000$ grain weight $\left(E_{2}\right.$ and $\left.E_{4}\right)$ and harvest index $\left(E_{1}\right)$; whereas, excess of recessive genes were noticed for days to $50 \%$ heading $\left(\mathrm{E}_{1}\right)$, no. of effective tillers per plant $\left(E_{1}\right.$ and $\left.E_{3}\right)$, length of main spike $\left(E_{2}\right)$, no. of spikelets per main spike $\left(E_{2}\right.$ and $\left.E_{3}\right)$ and 1000 grain weight $\left(E_{1}\right.$ and $\left.E_{3}\right)$. The ratio $\left(\mathrm{H}_{2} / 4 \mathrm{H}_{1}\right)$ indicated a symmetrical distribution of positive and negative dominant genes in parents in all studied characters $^{24}$. 
The estimates of narrow sense heritability were low for days to $50 \%$ heading $\left(\mathrm{E}_{1}\right.$ and $\left.E_{3}\right)$, days to maturity $\left(E_{1}\right.$ and $\left.E_{3}\right)$, no. of effective tillers per plant $\left(E_{1}\right.$ and $\left.E_{3}\right)$, length of main spike $\left(E_{2}\right.$ and $\left.E_{3}\right)$, no. of spikelets per main spike $\left(E_{2}, E_{3}\right.$ and $\left.E_{4}\right)$, no. of grains per main spike $\left(E_{1}, E_{2}\right.$ and $\left.E_{4}\right)$, grain yield per main spike $\left(E_{2}\right.$ and $\left.E_{4}\right), 1000$ grain weight $\left(E_{1}, E_{2}, E_{3}\right.$ and $\left.E_{4}\right)$ and harvest index $\left(\mathrm{E}_{1}\right)$, which indicated that these characters were under greater influence of dominant gene effect. The narrow sense heritability was found moderate for days to $50 \%$ heading $\left(E_{2}\right.$ and $\left.E_{4}\right)$, which confirmed that these characters were under genetic control of both additive and dominant genes. Narrow-sense heritability was generally of small magnitude and ranged from $0.86 \%$ to $66.67 \%^{24}$.

\section{Graphical Analysis}

To test the validity of the basic assumptions postulated for diallel analysis (Hayman, 1954), Wr - Vr homogeneity " $\mathrm{t}$ " " test was performed. The value of " $\mathrm{t}^{2}$ " test was significant for majority of the characters either in $E_{1}, E_{2}, E_{3}$ and $E_{4}$, or in their different combinations, indicating failure of any of the basic assumptions of diallel analysis. However, further verification of the validity of assumption in respect to presence or absence of epistatic gene effects could be more precisely made from $\mathrm{Wr}-\mathrm{Vr}$ graph, the array points on the $\mathrm{Wr}-\mathrm{Vr}$ graph expected to fall on the line of unity $\left(45^{\circ}\right)$ and thereby the value of regression " $b$ " should be significantly deviated from zero, but not from one, suggesting the absence of epistatic gene effect. The regression value "b" was statically at par one for days to $50 \%$ heading $\left(\mathrm{E}_{1}\right.$ and $\left.\mathrm{E}_{4}\right)$ and 1000 grain weight $\left(E_{3}\right.$ and $\left.E_{4}\right)$, which revealed an absence of digenic interactions for these characters in respective environment (Table 4).

The graphical analyses are presented in Figure 3 to Figure 6 and are described as follows.

\section{Days to $50 \%$ heading}

In $E_{2}$, regression line $(Y=0.8771 x-0.7497)$ (Figure 3) intercepted the $\mathrm{Wr}$ axis below the origin indicating presence of over dominance gene action. Among the parents, HD 2864 had more frequency of dominant genes, as these parents occupied the nearest position to the origin of regression line, accordingly parents GW 366, HI 1544 and UAS 385 had more frequency of recessive genes, as those occupied the farthest position from the origin; while LOK 1, GW 322, GW 173 and GW 11 had equal proportion of dominant and recessive genes as those occupied an intermediate position on regression line. The parents GW 451 and GW 496 would be carrier of genes causing inter allelic interaction as those occupied their 
positions outside truncated area of the graph. The slope of regression line of $\mathrm{Wr}-\mathrm{Vr}$ graph was statistically of unity in $\mathrm{E}_{4}(\mathrm{Y}=0.6967 \mathrm{x}$ - 0.1504) (Figure 4) indicating absence of digenic interactions. Similarly, the regression line intercepted $\mathrm{Wr}$ axis passes through the origin indicating presence of complete dominance gene action.

Among the parents, HD 2864 and GW 496 had more frequency of dominant genes, as these parents occupied the nearest position to the origin of regression line, accordingly parents GW 366 and HI 1544 had more frequency of recessive genes, as both the genotypes occupied the farthest position from the origin; parents GW 451, LOK 1, GW 322, GW 11, GW 173 and UAS 385 had equal proportion of dominant and recessive genes as those occupied an intermediate position on regression line.

\section{0 grain weight}

Regression line $(\mathrm{Y}=0.711 \mathrm{x}$ - 2.5028) (Figure 5) intercepted $\mathrm{Wr}$ axis below the origin, indicating over dominance gene action for the character in $\mathrm{E}_{3}$. The array point of parent GW 451 was nearest to the origin, and thereby it was supposed to contribute excess of dominant genes. Whereas, the parent HD 2864 occupied its position at tail of regression line indicating it as carrier of excess of recessive genes. Moreover, rest of the parents viz., GW 451, GW 496, GW 322, HI 1544, GW 173, GW 11 and UAS 385 occupied intermediate positions on regression line indicating equal distribution of dominant and recessive genes with them. The parents LOK 1 and GW 366 could be carrier of genes causing inter allelic interaction as those occupied their positions outside the truncated area of the graph.

In $\mathrm{E}_{4}$, the slope of regression line of $\mathrm{Wr}-\mathrm{Vr}$ graph was linear and probably at par to one. The regression line $(\mathrm{Y}=0.6615 \mathrm{x}$ - 1.4252) intercepted the $\mathrm{Wr}$ axis below the origin indicating presence of over dominance gene action. The scattered array points of the parents on and around the regression line revealed existence of sufficient variability among the parents. The array point of LOK 1 occupied their position nearer to origin, indicating that it would likely to contribute dominant genes in high frequency; in contrast to this, parents GW 173, GW 11 and UAS 385 attained their positions at the tail of regression line indicating carrier of high frequency of recessive genes. Moreover, rest of the parents occupied intermediate positions on regression line within the truncated area indicating equal distribution of dominant and recessive genes with them (Figure 6).

\section{Discussion of graphical approach}


In graphical analysis, regression value " $\mathrm{b}$ " was unity for days to $50 \%$ heading ( $\mathrm{E}_{1}$ and $\left.E_{4}\right)$ and 1000 grain weight $\left(E_{3}\right.$ and $\left.E_{4}\right)$, which revealed an absence of digenic interactions for these characters in respective environment. Based on interception of regression line on $\mathrm{Wr}$ axis, degree of dominance was depicted as, over dominance for days to $50 \%$ heading $\left(\mathrm{E}_{2}\right)$, 1000 grain weight $\left(\mathrm{E}_{3}\right.$ and $\left.\mathrm{E}_{4}\right)$, whereas, complete dominance for days to $50 \%$ heading $\left(\mathrm{E}_{4}\right)$. The dispersion of parents around the regression line revealed that parents 3,1 and 2 were close to the origin of the coordinate, and accordingly had $>75 \%$ of dominant genes, parents 4 and 6 had 50\% dominant genes, while parent 5 was far from the origin and therefore had mostly recessive genes ${ }^{24}$.

\section{Conclusions}

Components of gene effect revealed that most of the characters were governed by both additive and dominance gene action across the environments with greater influence of dominance gene effect except for days to $50 \%$ heading in $\mathrm{E}_{1}, \mathrm{E}_{2}, \mathrm{E}_{3}$ and $\mathrm{E}_{4}$; days to maturity in $E_{2}, E_{3}$ and $E_{4}$; grain yield per main spike in $E_{4}$; sedimentation value in $E_{2}$ and $E_{4}$, gluten; wet gluten in $\mathrm{E}_{4}$; starch content in $\mathrm{E}_{2}$ and iron content in $\mathrm{E}_{2}$. Therefore, population improvement may be followed to isolate superior recombinants for development of desired parent/s in future breeding programme.

The character grain yield per plant was influenced by over dominance gene effect. Therefore, while selecting segregants for improvement of yield attributing traits. Selection may be delayed by the time dominance will be diluted and transgressive segregants could be identified.

In graphical analysis, regression value "b" was unity for days to $50 \%$ heading $\left(\mathrm{E}_{1}\right.$ and $\left.E_{4}\right), 1000$ grain weight $\left(E_{3}\right.$ and $\left.E_{4}\right)$, protein content $\left(E_{1}\right.$ and $\left.E_{3}\right)$, sedimentation value $\left(E_{1}, E_{2}\right.$ and $\left.E_{3}\right)$ and starch content $\left(E_{1}\right)$, which revealed an absence of digenic interactions for these characters in respective environment. Rest of the characters had non-random distribution of genes at different loci among the parents and/ or presence of inter allelic interaction at different loci. The contradiction between the approaches of as genetic component of variation and $\mathrm{Vr}-\mathrm{Wr}$ graph analysis could be ascribed to the presence of correlated gene distribution ${ }^{\mathbf{1 1}}$.

\section{MATERIALS AND METHODS}

Plant material and field performance evaluation. The experimental material comprised of 10 parents, their 45 hybrids and 2 check varieties. The crosses were made during Rabi 201718 \& 2018-19 through $10 \times 10$ diallel mating excluding reciprocals. The parents, hybrids and 
standard checks were evaluated in complete randomized block design with three replication in the Regional Research Station, Anand Agricultural University, Anand, India $\left(22^{\circ} 35^{\prime} \mathrm{N}\right.$, $72^{\circ} 55^{\prime}$ E) during normal and late sown conditions in four environments $E_{1}$ and $E_{2}$ (normal and late sown, Rabi 2018-19), $\mathrm{E}_{3}$ and $\mathrm{E}_{4}$ (Normal and late sown Rabi 2019-20) (Table 2). Each treatment consists, each female lines of 3 meter length were grown with $20 \times 10$ (Normal) and $18 \times 10$ (Late) $\mathrm{cm}$ inter and intra row spacing, respectively.

All the recommended package of practice followed for raising the crop. The observations were recorded on yield and its ten component traits viz., (Plant height, Days to $50 \%$ flowering, Days to maturity, No. of effective tillers per plant, Length of main spike, No. of spikelets per main spike, No. of grains per main spike, 1000 grain weight, Grain yield per main spike, Grain yield per plant and Harvest index). The details of the parental genotypes, Checks and Hybrid crosses are given in Table 1 and 3. None of the wheat germplasm was procured from outside of the institute since it is available with the institute or it is in the public domain. The guidelines and legislation are not applicable in this study.

Statistical analysis. The data recorded on studied traits in parents and hybrids were subjected to components of genetic variance using general linear model as implemented in SPAR01. In addition, numerical approach and graphical approach were calculated.

Estimation of numerical and graphical approach. For each parents these approaches were estimated.

Competing interests. Authors have declared that no competing interests exist.

\section{REFERENCES}

1. Khodadadi, E., Aharizad, S., Sabzi, M. \& Khodadadi E. Studding the genetic control of the bread quality related traits of wheat using Hayman graphical method. Annals of Biological Research 3 (12), 5446-5449 (2012).

2. Khan, Riaz, K.M. and Khan, S.M. Graphical analysis of spike characters related to grain yield in bread wheat (Triticum aestivum L.). Pakistan Journal of Biological Sciences 2 (2): 340-343 (1999).

3. Gami, R. A., Chauhan B. B. \& R. N. Patel. (Hayman's diallel analysis for yield and attributing traits in sesame (Sesamum indicum L.). Electronic Journal of Plant Breeding (2020). DOI: 10.37992/2020.1102.064. 
4. Patel, A. L. and Kathiria, K. B. Graphical analysis for fruit yield and its component traits in chilli (Capsicum annuum L.). Electronic Journal of Plant Breeding 9 (3), 926 - 932 (2018).

5. Kearsey, M. J. Biometrical analysis of a random mating population; a comparison of five experimental designs. Heredity 20, 205-235 (1965).

6. Jinks, J. L. and Hayman, B. I. The analysis of diallel crosses. Maize Genetics Newsletter 27, 48-54 (1953).

7. Griffing, B. A general treatment of the use of diallel cross in quantitative inheritance. Heredity 10, 31- 50 (1956).

8. Hayman, B. I. The theory and analysis of diallel crosses. Genetics 39, 789-809 (1954b).

9. Pooni, H. S., Jinks, J. L. \& Singh, R. K. Methods of analysis and the estimation of the genetic parameters from a diallel set of crosses. Heredity 52, 243-253 (1984).

10. Wright, A. J. Diallel designs, analysis and reference populations. Heredity 54, 307311 (1985).

11. Hayman, B. I. The analysis of variation of diallel tables. Biometrics 10, 235-244 (1954a)

12. Hayman, B. I. Interaction, heterosis and diallel crosses. Genetics 42, 336-355 (1957).

13. Hayman, B. I. The separation of epistasis from additive and dominance variation in generation means. Heredity 12, 371-390 (1958).

14. Hayman, B. I. The theory and analysis of diallel crosses III. Genetics 45, 155-172 (1960).

15. Jinks, J. L. The analysis of continuous variation in a diallel cross of Nicotiana rustica varieties. Genetics 39.767-788 (1954).

16. Jinks, J. L. The $F_{2}$ and backcross generations from a set of diallel crosses. Heredity 10, 1-30 (1956).

17. Mather, K. and Jinks, J. L. Book: Biometrical genetics, the study of continuous variation. ( ${ }^{\text {rd }}$ Ed.). UK: Chapman and Hall Ltd., London (1982).

18. Singh, R. K. and Chaudhary, B. D. Biometrical methods in quantitative genetics. Kalyani Publishers, Ludhiana and Delhi. pp. 262-282 (1985).

19. Kushwaha, M. L. and Ram, H. H. Vr, Wr graphical analysis in bottlegourd. Vegetable Science 23, 162-165 (1996).

20. Dubey, S. K. and Maurya, I. B. Studies on heterosis and combining ability in bottlegourd. Indian Journal of Genetics 63, 148-152 (2003). 
21. Maurya, I. B. and Singh, S. P. Studies on gene action in long fruited bottlegourd. Crop Research 8, 100-104 (1994).

22. Dubey, R. K. and Ram, H. H. Graphical analysis (Vr-Wr) and numerical approach for a diallel analysis of yield components in Bottlegourd (Lagenaria siceraria (Mol.) Standl.) International Journal of Plant Breeding. Global Science Books. 1(1), 65-69 (2007)

23. Derera, J., Tongoona, P., Bindiganavile, S. V. and Laing, M. D. Gene action controlling grain yield and secondary traits in southern African maize hybrids under drought and non-drought environments. Euphytica 162, 411-422 (2008).

24. Al-Naggar, A. M. M., Atta, M. M. M., Ahmed, M. A. \& Younis, A. S. M. Numerical and graphical diallel analyses of maize (Zea mays L.) agronomic and yield traits under well watering and water deficit at silking. Archives of Current Research International 5(3), 1-18, (2016). 


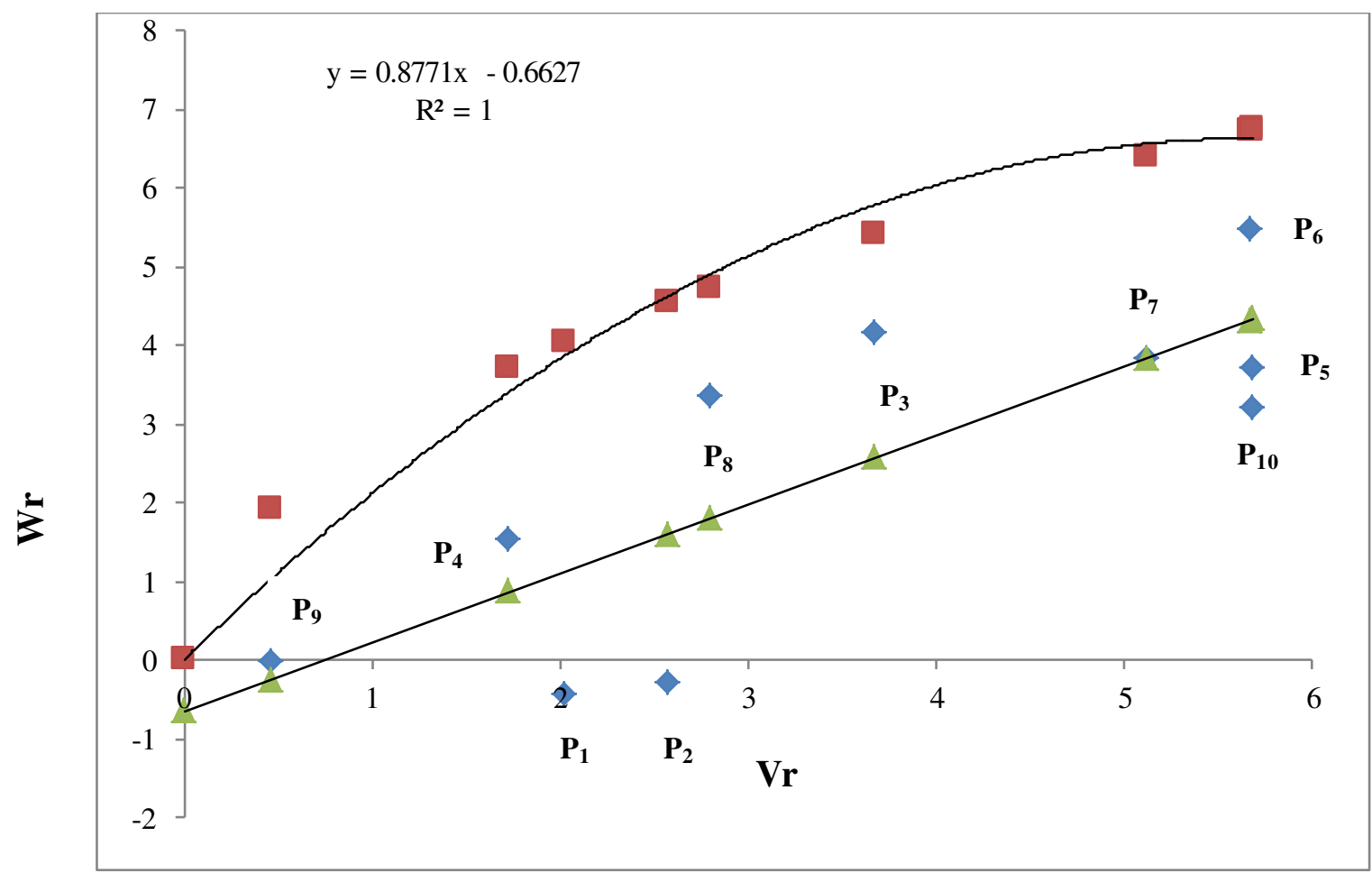

Fig 3: Wr- Vr graph for days to $50 \%$ heading in $\mathbf{E}_{2}$

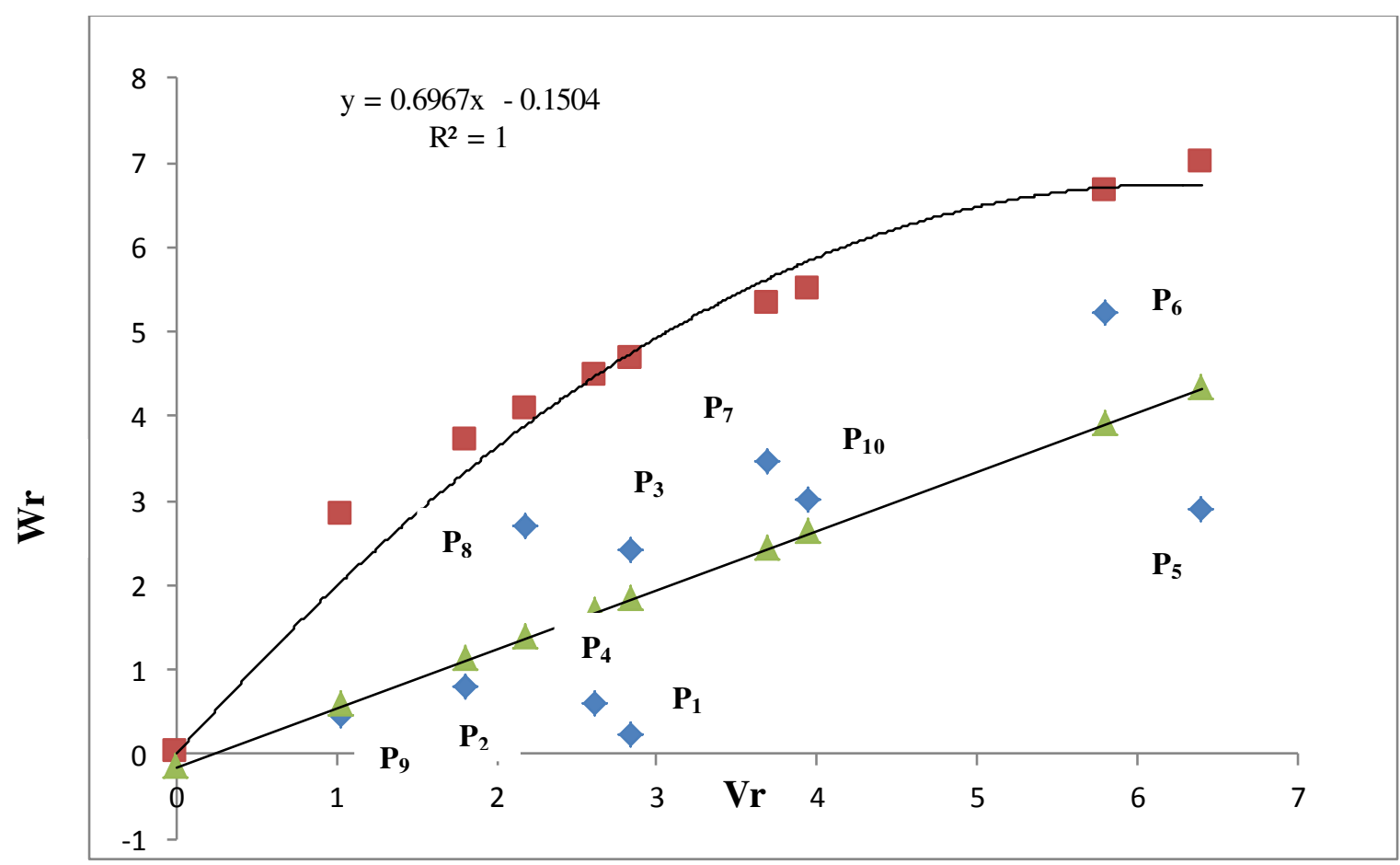

Fig 4: Wr- $\mathrm{Vr}$ graph for days to $50 \%$ heading in $\mathrm{E}_{4}$

$P_{1}=G W 451 ; P_{2}=G W$ 496; $P_{3}=$ LOK $1 ; P_{4}=G W 322 ; P_{5}=G W 366 ; P_{6}=H I 1544 ; P_{7}=G W$ $173 ; P_{8}=$ GW 11; $P_{9}=$ HD 2864; $P_{10}=$ USA 385

Darabola 1 Regression $\quad$ Poly.(parabola) - Linear(Regression) 


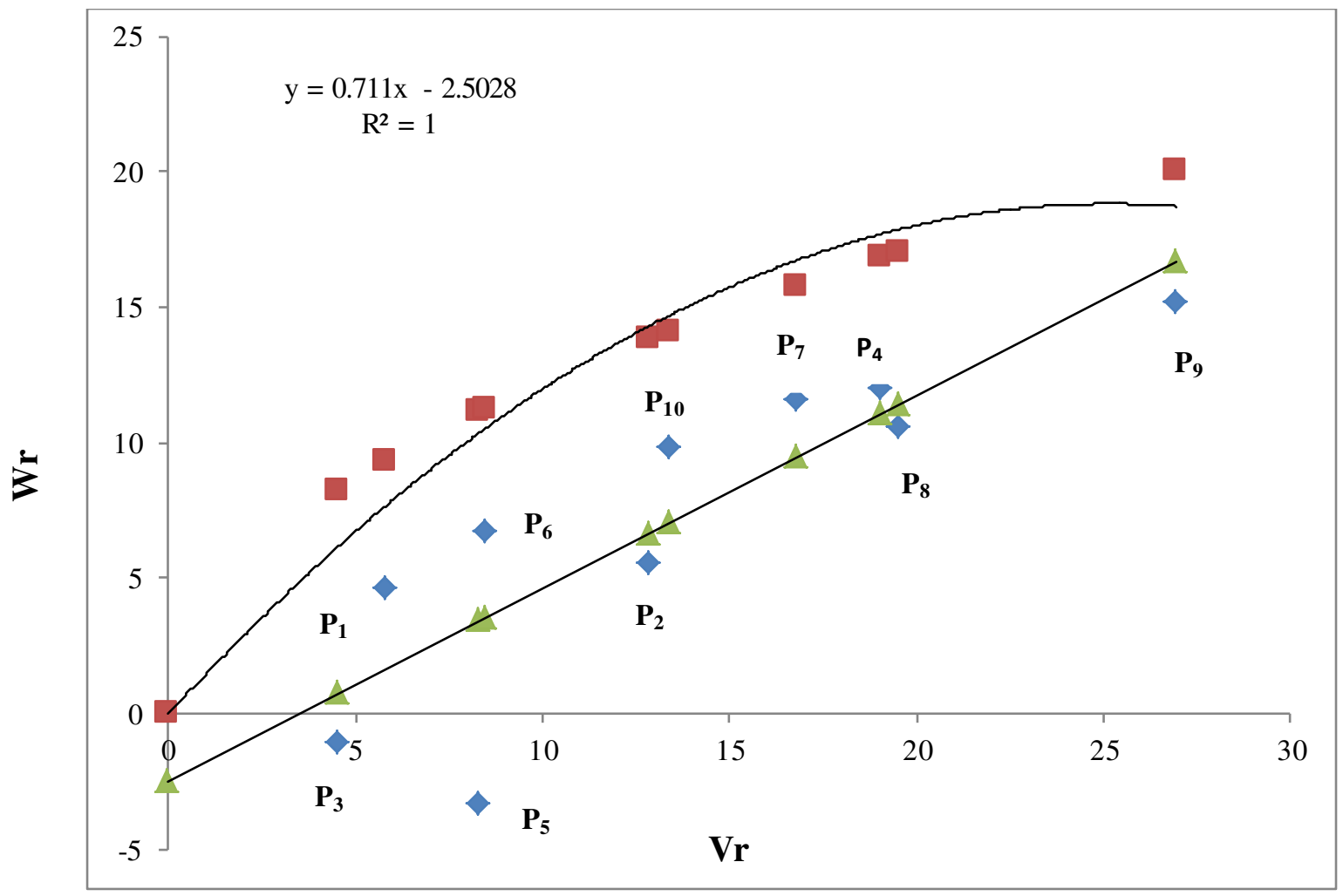

Fig. 5: Wr- Vr graph for 1000 grain weight in $E_{3}$

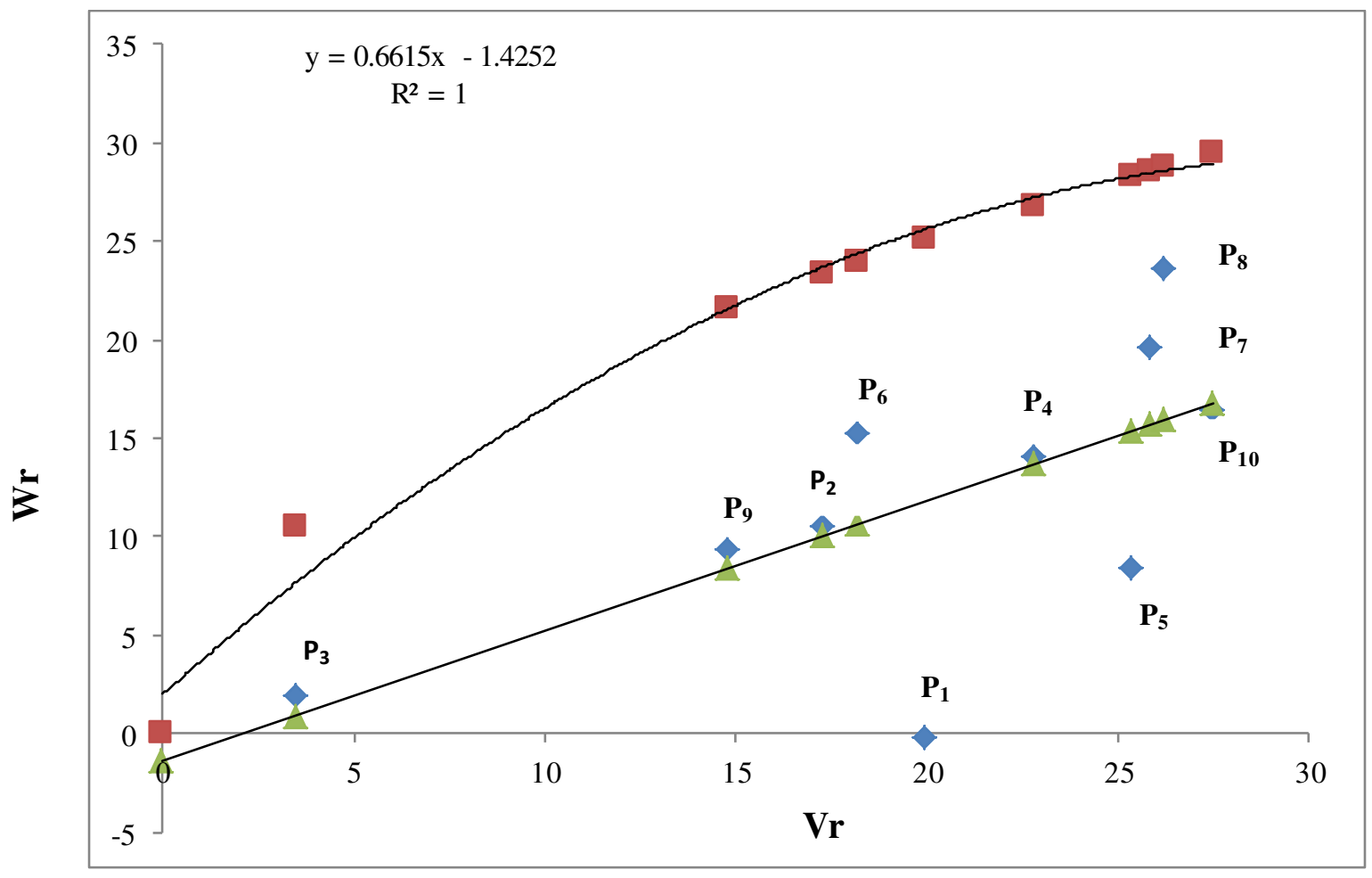

Fig 6: Wr- Vr graph for 1000 grain weight in $\mathbf{E}_{4}$

$P_{1}=$ GW 451; $P_{2}=$ GW 496; $P_{3}=$ LOK $1 ; P_{4}=$ GW 322; $P_{5}=$ GW 366; $P_{6}=$ HI 1544; $P_{7}=G W$ 173; $P_{8}=$ GW 11; $P_{9}=$ HD 2864; $P_{10}=$ USA 385 